Cómo citar este trabajo: Duval, V. S., \& Campo, A. M. (2018). Patrimonio geomorfológico y geodiversidad en las Sierras de Lihué Calel (Argentina). Boletín de la Asociación de Geógrafos Españoles, 79, 2476, 124. http://dx.doi.org/10.21138/bage.2476

\title{
Patrimonio geomorfológico y geodiversidad en las Sierras de Lihué Calel (Argentina)
}

\author{
Geomorphological heritage and geodiversity \\ in the Sierra de Lihué Calel, Argentina
}

\author{
Valeria Soledad Duval \\ valeria.duval@uns.edu.ar \\ Alicia María Campo \\ amcampo@uns.edu.ar \\ CONICET \\ Universidad Nacional del Sur (Argentina)
}

\begin{abstract}
Resumen
El objetivo del trabajo fue valorar el patrimonio geomorfológico del Parque Nacional Lihué Calel (La Pampa, Argentina) con el fin de contribuir al conocimiento de su geodiversidad. Para ello, se identificaron las geoformas de las sierras y se aplicó el método de González Trueba y Serrano Cañadas (2005) sobre los geomorfositios. Se valoraron siete sitios según sus características intrínsecas, aspectos culturales, educativos y forma actual de uso y gestión. Dos de ellos tienen un valor mayor ya que además del recurso natural cuentan con equipamiento y son un atractivo turístico del área protegida.
\end{abstract}

Palabras clave: geomorfositio; patrimonio geomorfológico; geodiversidad; Sierras de Lihué Calel.

\begin{abstract}
The aim of this work was to evaluate the geomorphological heritage of Lihué Calel National Park (La Pampa, Argentina) in order to contribute to the knowledge of its geodiversity. For this, the geoforms of the mountain range were identified and the method of González Trueba and Serrano Cañadas (2005) on the geomorphosites was applied. Seven sites were evaluated according to their intrinsic
\end{abstract}


characteristics, cultural, educational aspects and current form of use and management. Two of them have a higher value because besides the natural resource they have equipment and are a tourist attraction of the protected area.

Key words: geomorphosite; geomorphological heritage; geodiversity; Lihué Calel National Park.

\section{Introducción: el patrimonio geomorfológico en áreas protegidas}

El patrimonio natural es el conjunto de elementos, bienes y paisajes que por sus características internas merecen ser conservados y brindan múltiples beneficios a la sociedad. En particular, el patrimonio geomorfológico está siendo revalorizado a nivel mundial especialmente en las últimas décadas (González Trueba \& Serrano Cañadas, 2008; Palacio Prieto, 2013; Artugyan, 2014; González Amuchastegui et al., 2014). En Argentina, se comenzó a trabajar sobre estas temáticas a partir de la década de 1990 (Palacio Prieto, 2016) cuyos avances se esbozan en el Congreso Geológico Argentino, destacando principalmente el patrimonio geológico (Leynaud, 2002; Martínez, 2008; Medina, 2014).

La evaluación de los sitios geomorfológicos tiene una connotación más cultural, vinculando el aspecto físico con el antrópico, lo cual genera un valor añadido y cobra un mayor interés por lo paisajístico, por su dinámica y su estructura. En el contexto de las áreas protegidas, estos lugares deberían ser aprovechados con uso de tipo recreativo, turístico y didáctico. En España y México, hay iniciativas que proponen hacer una utilización sustentable del relieve haciendo hincapié en la interpretación de su patrimonio (Mendoza Ontiveros et al., 2011; Bazán, 2016). Por otro lado, en Argentina Mikkan (2016), identificó el patrimonio geomorfológico y realizó en mapa de geodiversidad del Monumento Natural de la Reserva La Payunia, Mendoza.

Los geomorfositios o lugares de interés geomorfológico son geoformas que poseen un valor geomorfológico, histórico, cultural, estético y/o socioeconómico, los cuales merecen ser protegidos ya que forman parte del patrimonio natural (González Trueba \& Serrano Cañadas, 2008). Este concepto fue introducido por Reynard y Panizza (2007) en contraste con el de geositio el cual posee una connotación geológica y más histórica. Los geomorfositios poseen una vinculación directa con lo espacial incorporando además de la variable natural, el aspecto antropogénico a través de su importancia en lo cultural y socioeconómico.

En el Parque Nacional Lihué Calel, la valorización de las sierras desde el punto de vista de la geodiversidad tiene actualmente poco desarrollo. En relación con el patrimonio geológico, Llambías y Leveratto (1975) y Linares et al. (1980) realizaron los primeros estudios geológicos regionales que sentaron las bases para los trabajos de Llambias (2008) y Aguilera et al. (2014). En estos se realizó la descripción geológica del sitio y la identificación de las geoformas del relieve grafítico. Estos antecedentes permiten aplicar metodologías para identificar y valorar geomorfositios. Es por ello 
que el objetivo del presente trabajo fue valorar el patrimonio geomorfológico del Parque Nacional Lihué Calel con el fin de contribuir con el conocimiento de su geodiversidad.

\section{2 Área de estudio}

El Parque Nacional Lihué Calel es un área protegida de jurisdicción nacional que se localiza en el centro-sur de la provincia de La Pampa, Argentina (Figura 1). Se creó en 1977 con el objetivo de preservar las sierras homónimas. De acuerdo con Cabrera (1976) pertenece a la provincia fitogeográfica del Monte. El clima es cálido y seco con gran variedad térmica entre estaciones y las precipitaciones son muy variables disminuyendo hacia el oeste de 400 a 80 mm aproximadamente. La estación seca dura hasta un máximo de nueve meses y el periodo de mayor precipitación se produce en la estación más cálida (Pol et al., 2006). Como parte de la biodiversidad, se destacan dos endemismos que son Gaillardia cabrerae (margarita pampeana) y Adesmia lihuelensi y solo se distribuyen en el interior del área protegida. También posee un patrimonio cultural de importancia con las pinturas rupestres y los yacimientos arqueológicos que son relictos de los pueblos originarios.

El parque cuenta con tres tipos de ambientes: el jarillal, el serrano y el salitral. El primer grupo se caracteriza por ser un relieve de llanura y por presentar vegetación arbustiva con predominio del género Larrea y cuya comunidad vegetal es el jarillal, dentro de la provincia fitogeográfica del Monte. El ambiente serrano está compuesto por las sierras de Lihué Calel en el cual se encuentra el cerro Alto que es la mayor altura de la provincia y en conjunto son el mayor atractivo del parque. Otros cerros de menor altura como el cerro Fortaleza, cerro de La Virgen, cerro Cortado también poseen importancia a escala regional (Figura 2). El ambiente del salitral se extiende en el sector norte del parque e incluye el salitral Levalle y los alrededores donde la influencia del suelo salino persiste.

El relieve es uno de los elementos de mayor importancia en la configuración de las áreas protegidas y junto con la vegetación forman parte del aspecto visible del paisaje (González Amuchastegui et al., 2014). Las sierras de Lihué Calel pertenecen a un relieve litológico donde el tipo roca es el elemento que influye en el modelado del paisaje. Dentro de este gran grupo, el modelado granítico es el correspondiente al área de estudio. Las sierras se encuentran sobre una meseta de roca ignimbrita riolítica que forma parte del Bloque de Chadileuvú. Su origen es Permo-Triásico con una edad aproximada de 240 millones de años. Este paisaje se mantuvo estable, sin actividad magmática posterior ni deposición de sedimentos marinos. La topografía fue recubierta por una capa de sedimentos eólicos (limo, limo-arenoso y arena-limosa) hacia fines del Mioceno en la era Cenozoica. Además el proceso de peneplanización, de constante equilibrio entre la erosión y sedimentación, contribuyó a modelar el paisaje constituido por un inselberg (Sierras de Lihué Calel) rodeado de una llanura con suaves ondulaciones (Aguilera et al., 2014). 
Figura 1. Localización del Parque Nacional Lihué Calel en la Pampa
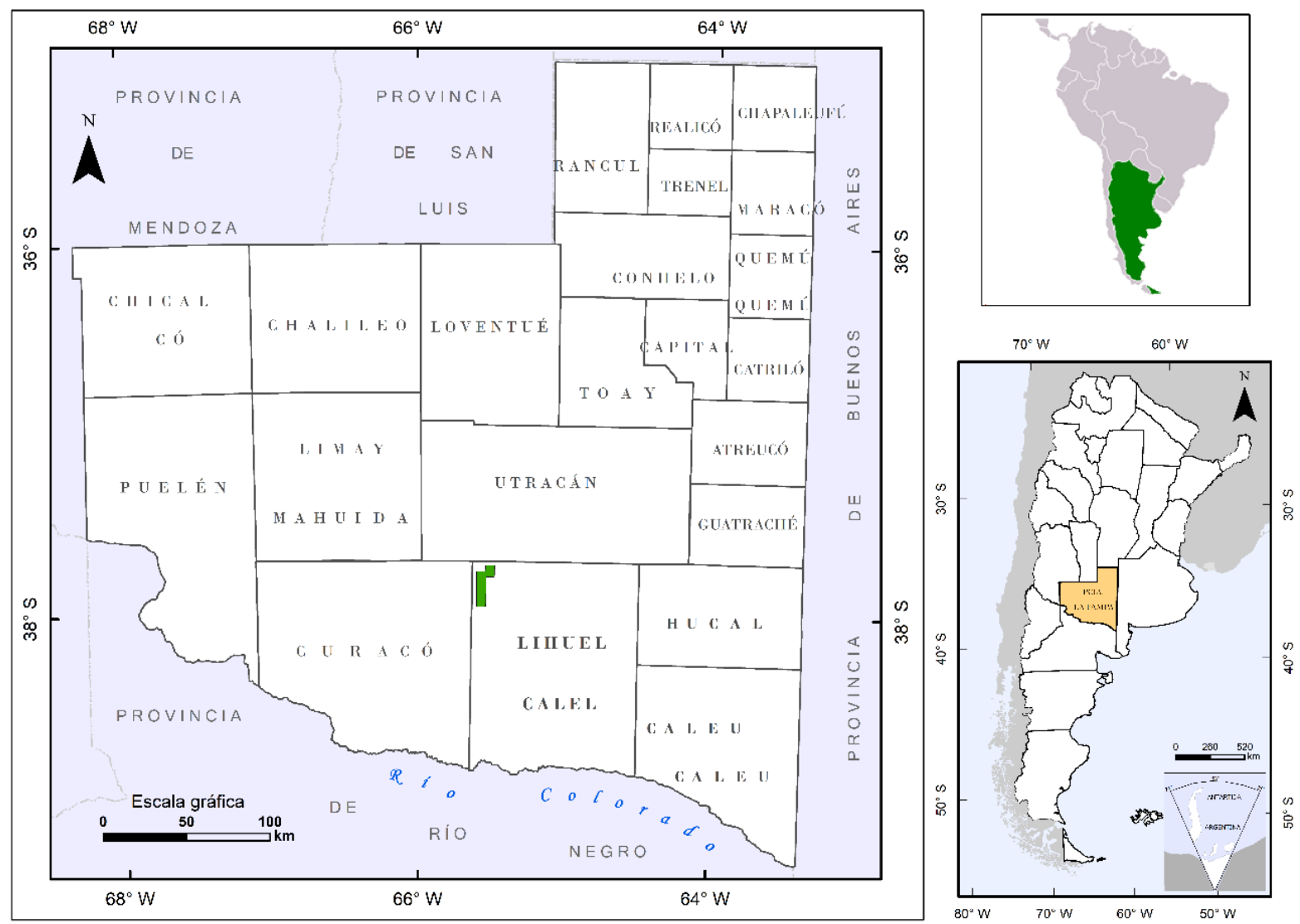

Fuente: elaboración propia

Este inselberg se compone de roca ignimbrita riolítica estratificada en distintas secuencias como producto de flujos piroclásticos. Los mismos fueron generados por el colapso de una caldera sobre la cual se acumularon y se superpusieron las diferentes capas de material volcánico. Cada banco posee un espesor no superior a $1000 \mathrm{~m}$ de profundidad y el proceso de enfriamiento fue lento lo cual ocasionó grandes cristales, razón por la cual estas rocas poseen una fisonomía similar a la del granito. La caldera es de tipo Downsag y se caracteriza por tener una topografía inclinada hacia adentro y ausencia de fallas. 
Figura 2. Localización de los cerros en el Parque Nacional Lihué Calel

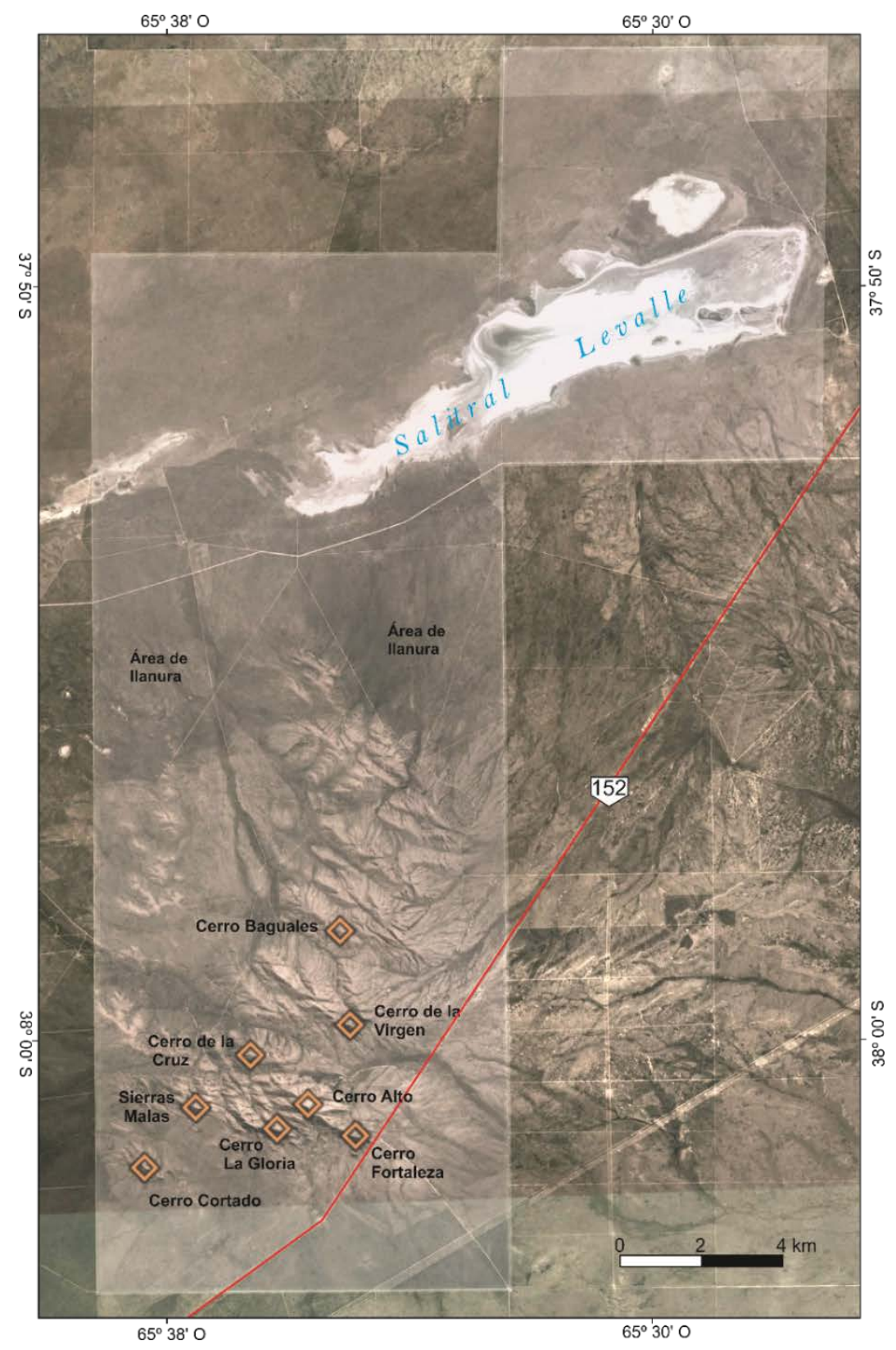

Fuente: elaboración propia sobre una imagen satelital de Google Earth Pro (2017)

\section{Metodología}

La identificación del patrimonio geomorfológico del Parque Nacional Lihué Calel se realizó considerando la metodología de González Trueba y Serrano Cañadas (2005) modificado por González Amuchastegui et al. (2014). En esta última se realiza una valoración de los geomorfositios y como resultado se obtiene un mapa de geodiversidad donde se destacan los sitios de mayor relevancia. Para ello, en primer lugar se realizaron observaciones directas sobre el terreno de las geoformas mayores y menores del relieve granítico de las sierras. Posteriormente se establecieron los geomorfositios a los cuales se los calificó según su valor intrínseco, añadido y de gestión para lo que se utilizaron fichas cuantitativas de cada sitio de interés (Tabla 1). 
Como paso previo se elaboró el mapa geomorfológico del área para el cual se utilizaron diferentes fuentes de información como los mapas geológicos de General Acha (3766-IV) y Puelches (3966-II) a escala 1:250.000, el croquis geológico de Llambías (2008), las cartas topográficas de Puelches, Sierra Chata y Sierra Chica de escala 1:100 000, las imágenes satelitales del área de LANDSAT 8 OLI, el Google Earth Pro ${ }^{\circledR}$, entre otros. La elaboración de la leyenda se realizó sobre la base de Peña Monné (1997). Este mapa permitió la identificación de los geomorfositios dentro del área protegida.

\section{Tabla 1. Ficha de valorización de los geomorfositios}

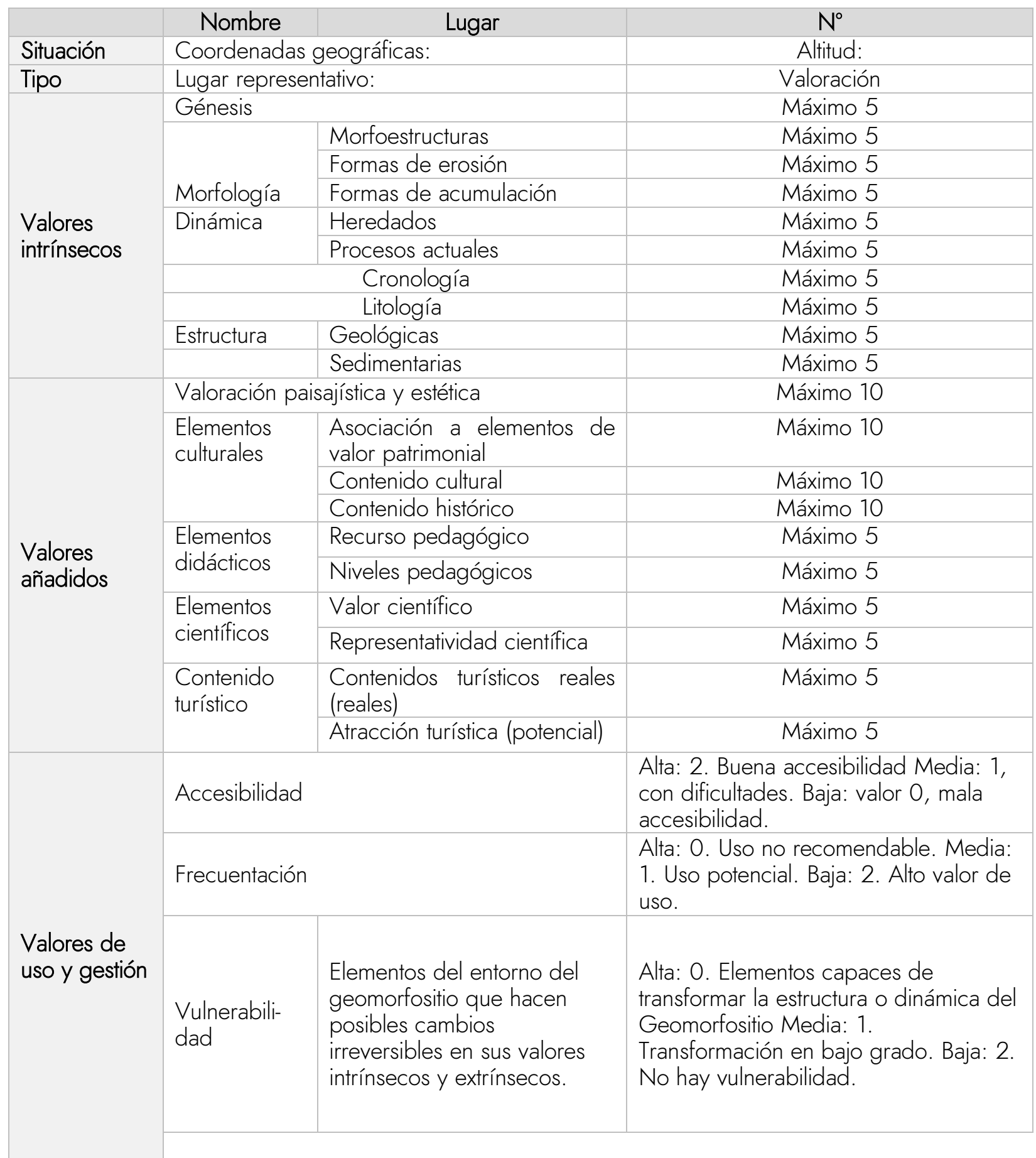




\section{Tabla 1. Continuación}

\begin{tabular}{|c|c|c|c|}
\hline & Nombre & Lugar & $\mathrm{N}^{\circ}$ \\
\hline \multirow{6}{*}{$\begin{array}{l}\text { Valores de } \\
\text { uso y gestión }\end{array}$} & $\begin{array}{l}\text { Intensidad de } \\
\text { uso }\end{array}$ & Uso actual del geomorfositio. & $\begin{array}{l}\text { Alta: O. Alta frecuentación, no permite } \\
\text { el incremento de actividades. Media: } 1 . \\
\text { Frecuentación y uso moderado. Baja: } \\
\text { 2. Frecuentación y uso muy moderado. }\end{array}$ \\
\hline & $\begin{array}{l}\text { Riesgo de } \\
\text { degradación }\end{array}$ & $\begin{array}{l}\text { Posibilidad de deterioro del } \\
\text { geomorfositio con su uso } \\
\text { hasta perder valores } \\
\text { intrínsecos y añadidos. }\end{array}$ & Alto: O. Medio: 1. Bajo: 2. \\
\hline & \multicolumn{2}{|c|}{ Estado de conservación } & $\begin{array}{l}\text { Alto: 2. Permite su uso. Medio: 1, Uso } \\
\text { restringido. Bajo: } 0 \text {. No favorece su } \\
\text { uso. }\end{array}$ \\
\hline & \multicolumn{2}{|l|}{ Impactos } & $\begin{array}{l}\text { Alto: O. Desaconsejan su uso, con } \\
\text { orientaciones de restauración. Medio: } \\
\text { 1. Permiten usos pero aconsejan } \\
\text { restauración o eliminación de impactos. } \\
\text { Bajo: 2. No hay impactos intensos }\end{array}$ \\
\hline & \multicolumn{2}{|c|}{ Condiciones de observación } & Alto: 2. Medio: 1. Bajo: 0 \\
\hline & \multicolumn{2}{|c|}{ Límites de cambio aceptables } & $\begin{array}{l}\text { Alto: 0. Baja fragilidad y débil } \\
\text { intensidad de uso, los cambios no } \\
\text { implican pérdida de valores. Medio: } 1 . \\
\text { Fragilidad y usos actuales permiten } \\
\text { cambios moderados sin pérdida de } \\
\text { valores. } \\
\text { Bajo: } 2 \text {. Elevada fragilidad o intensidad } \\
\text { de usos, el cambio implica pérdida de } \\
\text { valores. }\end{array}$ \\
\hline $\begin{array}{l}\text { Valoración } \\
\text { Global }\end{array}$ & & & \\
\hline
\end{tabular}

Fuente: González Amuchastegui et al. (2014)

La suma de los valores intrínsecos, los valores añadidos y el valor de uso y gestión da como resultado el valor total del geomorfositio. En la tabla 2 se muestran los valores de cada categoría considerando una escala cuantitativa y cualitativa. Con esos valores se espacializó la información de cada geomorfositio en el mapa de geodiversidad.

Tabla 2. Valores intrínsecos, añadidos, y de uso y gestión

\begin{tabular}{|c|c|c|c|}
\hline Valor intrínseco & Valor añadido & $\begin{array}{c}\text { Valor uso y } \\
\text { gestión }\end{array}$ & $\begin{array}{c}\text { Valor total del } \\
\text { geomorfositio }\end{array}$ \\
\hline$>8-10$ (Muy alto) & $>8-10$ (Muy alto) & $>6-10$ (Alto) & $>8-10$ (Muy alto) \\
\hline$>6-8$ (Alto) & $>6-8$ (Alto) & $>3-6$ (Medio) & $>6-8$ (Alto) \\
\hline$>4-6$ (Medio) & $>4-6$ (Medio) & $0-3$ (Bajo) & $>4-6$ (Medio) \\
\hline$>2-4$ (Bajo) & $>2-4$ (Bajo) & & $>2-4$ (Bajo) \\
\hline $0-2$ (Muy bajo) & $0-2$ (Muy bajo) & & $0-2$ (Muy bajo) \\
\hline
\end{tabular}

Fuente: elaboración propia

Para realizar el mapa de geodiversidad se utilizaron diferentes fuentes cartográficas de información como las hojas geológicas de General Acha (3766-IV) y Puelches (3966-II) a escala 1:250.000, el 
croquis geológico de Llambías (2008), las cartas topográficas de Puelches, Sierra Chata y Sierra Chica de escala 1:100.000, las imágenes satelitales del área de LANDSAT 8 OLI, el Google Earth Pro $®$, entre otros.

\section{Resultados}

\subsection{Geoformas de relieve}

En las sierras de Lihué Calel se reconocen geoformas mayores y menores. Su clasificación corresponde a diversos autores tales como Pedraza Gilsanz (1996), Vidal Romaní y Twidale (1998) y Martín Sánchez y Rebollada Casado (2010). En el grupo de las geoformas mayores se identifican inselberg, domos, nubbins o berrocales, rocas acastilladas o castle koppies, pedrizas y tors. Estas geoformas poseen un grado de meteorización distinta en el cual los crestones pertenecen a la fase inicial y la arenización a la fase final, donde el relieve granítico se desintegró en su totalidad (Figura 3).

\section{Figura 3. Evolución del paisaje granítico}

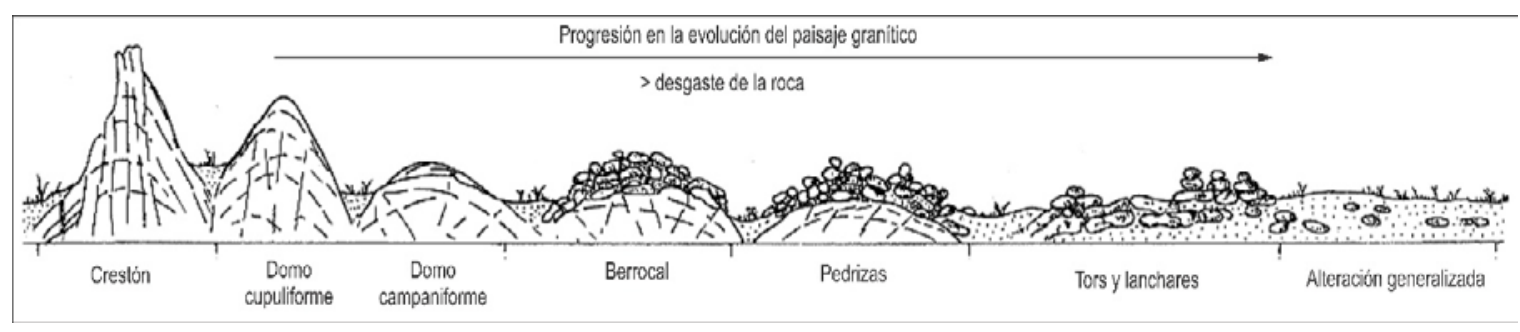

Fuente: elaboración propia modificado de Pedraza (1996)

A continuación se describen las geoformas mayores:

* Un inselberg (Figura 4a) es una cadena montañosa, de sierras y/o colinas aisladas que se destaca abruptamente entre las llanuras que los circundan. Las sierras de Lihué Calel constituyen en sí mismas un inselberg rodeado por una amplia llanura.

* Los domos (Figura 4b) son cúpulas de gran tamaño que se originan en la roca cuando las fracturas formadas no están muy próximas entre sí y la meteorización es baja. Pertenece a los primeros estadios de evolución del paisaje granítico.

* Los castle koppies (Figura 4c) son comparativamente pequeños acastillados residuales limitados por paredes muy inclinadas.

* Los nubbins o berrocales (Figura 4d) son colinas recubiertas por bolos o bloques dispersos. Este tipo de geoformas se encuentran en distintos cerros como el cerro Alto y el cerro de La Virgen. 
* Las pedrizas (Figura 4e) son formas de relieve granítico con un proceso de mayor degradación con respecto a los berrocales. Poseen diaclasamiento vertical, horizontal y curvo. En general, estas geoformas se localizan en las laderas más expuestas al sol.

* Los tors (Figura 4f) son bloques de roca dispersos que se originaron como producto de la meteorización.

* Los lanchares (Figura 4g) son rocas de superficie plana originados por el desgaste sobre diaclasas horizontales.

En el segundo grupo se identifican los tafonis, los alvéolos de arenización, las gnammas y las superficies de erosión.

* Los tafonis (Figura 5a) son concavidades, de decímetros a metros, producidas sobre las paredes verticales de la roca producto de la meteorización química y eólica.

* Los alvéolos (Figura 5b) son oquedades de forma más o menos globular en la roca que pueden estar interconectadas o no y que en conjunto adquieren una forma de panal de miel. Se originan por disgregación diferencial de la roca.

* Los pilancones o las gnammas (Figura 5c) son pequeñas depresiones circulares o alargadas en la roca que se generan con el almacenamiento del agua.

* Las superficies de erosión (Figura 5d) pueden ser superficies de descamación esferoidal o bien canales. Las primeras son áreas donde la roca es erosionada en forma de capas de cebolla, producto de la meteorización química. Las segundas se refieren a depresiones lineales en una roca granítica horizontal por la cual circula el agua.

Figura 4. Geoformas graníticas mayores en las sierras de Lihué Calel

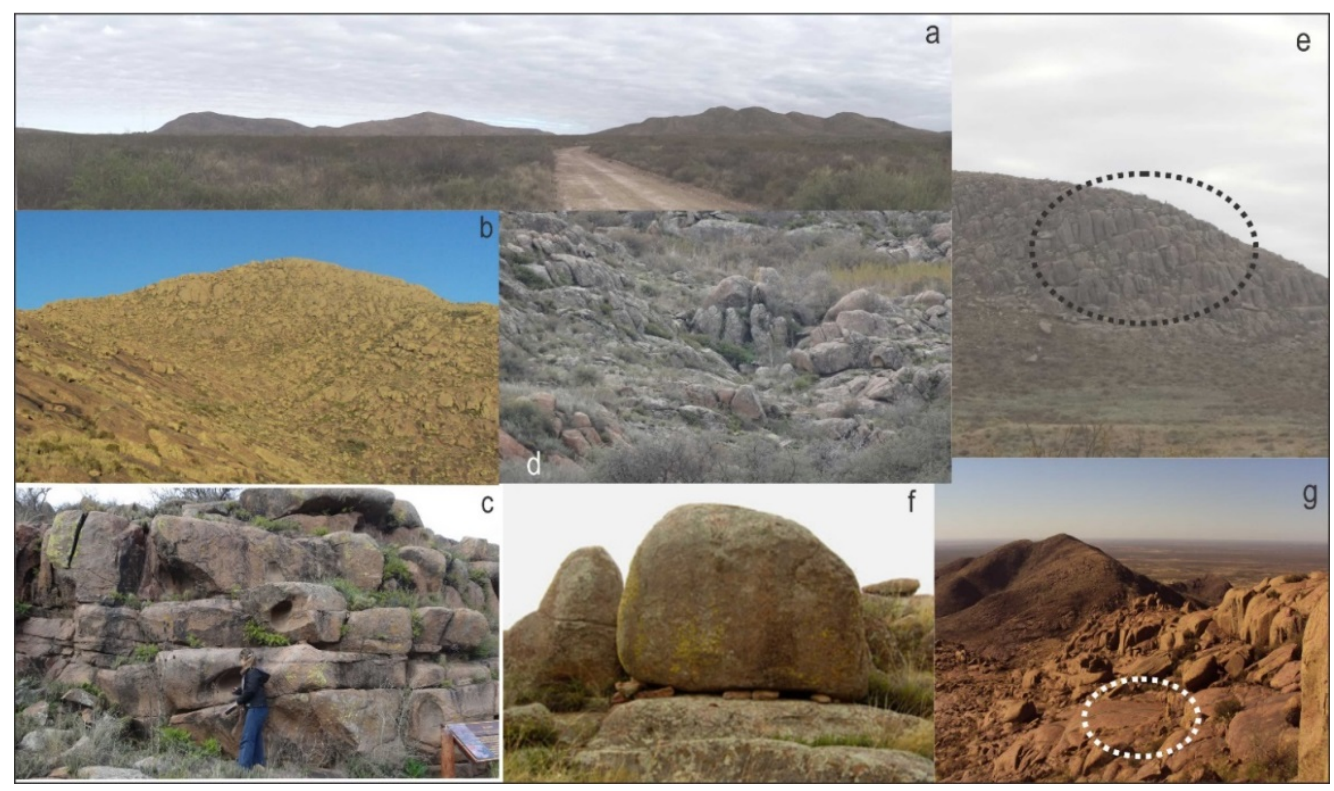

Fuente: elaboración propia 
Figura 5. Geoformas graníticas menores en las sierras de Lihué Calel

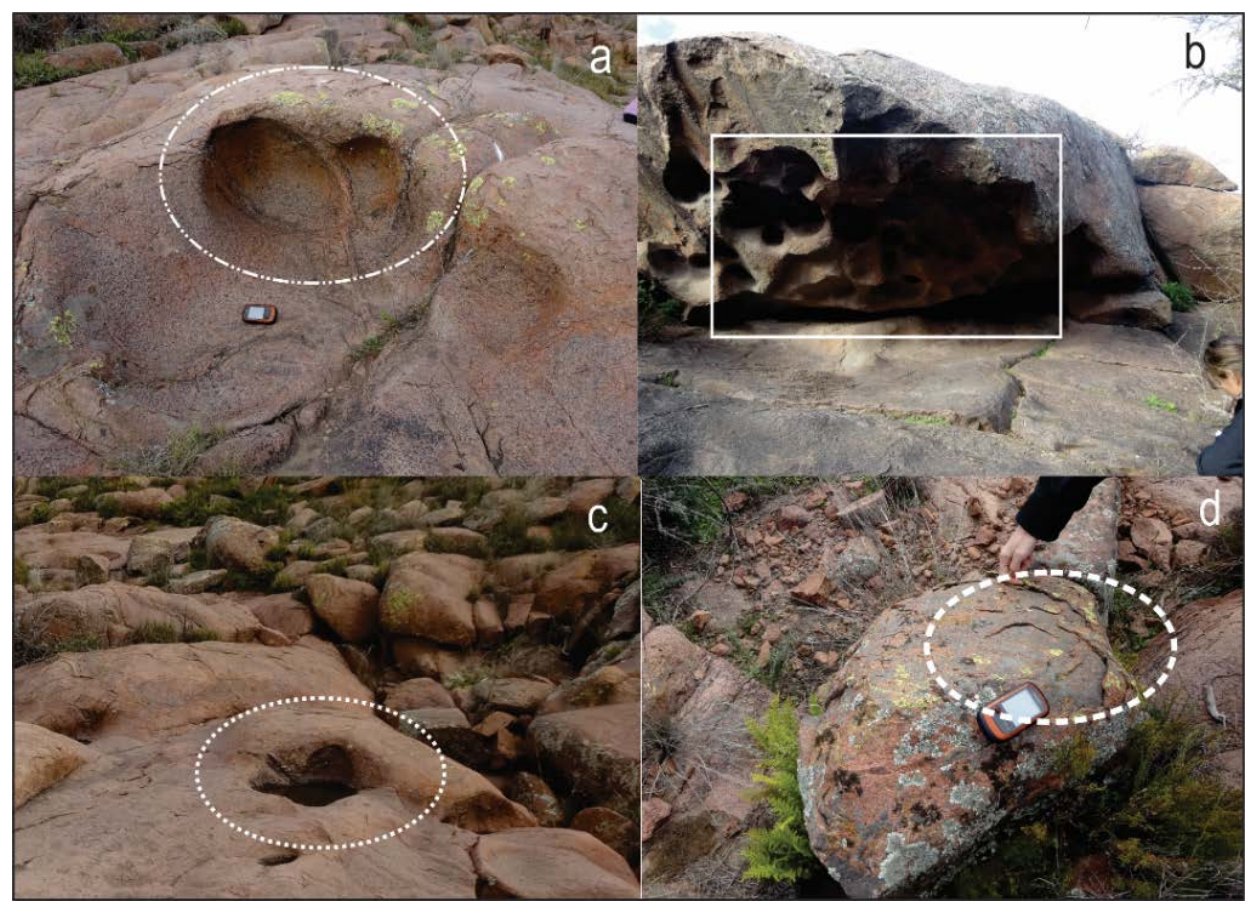

Fuente: elaboración propia

\subsection{Valoración de geomorfositios}

En el parque hay diversas geoformas litológicas del relieve granítico. Las sierras de Lihué Calel se consideran en sí como un inselberg que, descrito con anterioridad. Dentro de este conjunto de sierras se identificaron los siguientes geomorfositios: (1) valle de las pinturas, (2) cerro Alto o Sociedad Científica, (3) cerro de La Virgen, (4) cerro de La Gloria, (5) Sierras Malas, (6) área del salitral y (7) área de llanura.

El valle de las Pinturas ( $\left.38^{\circ} \mathrm{O}^{\prime} 34^{\prime \prime} \mathrm{S}-65^{\circ} 37^{\prime} 36^{\prime \prime} \mathrm{O}\right)$ se localiza en el sector suroeste del parque nacional. Se puede acceder a este a través de un camino vehicular y un camino peatonal. Del cartel inicial del sitio turístico hay un camino peatonal de $600 \mathrm{~m}$. En su trayecto, hay cartelería que comenta algunos elementos naturales relevantes. Es un lugar de gran importancia cultural ya que sobre la roca se encuentran las pinturas rupestres realizadas por pueblos originarios y valor arqueológico por emplazarse el Chenque I o enterratorio. Este sector es el lugar de mayor concentración con arte rupestre de la provincia. Además es el elemento de mayor valor turístico en el parque nacional y existe numerosa bibliografía relacionada con las manifestaciones y vida de estos pueblos.

Es un elemento de gran valor didáctico, utilizado como ejemplo, a nivel provincial, de los vestigios de los primeros pueblos. Con respecto al valor de uso y gestión este sitio posee una alta fragilidad interna y externa. Al tener acceso directo por parte de la sociedad, la frecuencia de visitación del lugar es elevada y, por lo tanto, la fragilidad interna y externa también. Entre las causas del 
deterioro de las pinturas se nombra: la alteración geofísica y geoquímica como resultado por ejemplo de la acreción de sales, la insolación, las variaciones térmicas y de la humedad y la erosión eólica, el deterioro geoquímico como solución (...) y bioquímico y biogeofísico: microorganismos, bacterias (...) (Ferraro, 2010, p. 220). También la acción humana afecta a este patrimonio a través de los graffitis o de los incendios de origen antropogénico (Ferraro, 2010).

En el sendero valle de las Pinturas se pueden encontrar diversos geomorfositios que son considerados como un valor intrínseco. Se puede destacar distintas geoformas de distinto orden como rocas acastilladas, tafoni y alvéolos. En la figura 6 se muestra uno de los sectores del sendero localizado a los $38^{\circ} 00^{\prime} 26^{\prime \prime} \mathrm{S}-65^{\circ} 37^{\prime} 3^{\prime \prime} \mathrm{O}$. En él se reconocen las rocas acastilladas o castle koppies que son pequeños residuales acastillados limitados por paredes muy inclinadas (Vidal Romaní \& Twidale, 1998, p. 206). Estos poseen fracturas ortogonales en sentido vertical y horizontal. En la fotografía se puede observar que las rocas acastilladas superiores poseen una forma más redondeada en relación con aquellas localizadas en la parte inferior. Por otro lado, se observan los tafoni que son cavidades en la roca originados, entre otras causas, por diferencia térmica, por el congelamiento-descongelamiento, por la meteorización biológica y por la desintegración granular debido a la cristalización de sales bajo un clima semiárido (Vidal Romaní \& Twidale, 1998).

La cueva del valle de las Pinturas se localiza a los $38^{\circ} 00^{\prime} 34^{\prime \prime} \mathrm{S}-65^{\circ} 37^{\prime} 36^{\prime \prime} \mathrm{O}$, es el punto final del sendero homónimo. Se localiza en las nacientes del arroyo de las sierras, tiene 1,80 m de altura por $6 \mathrm{~m}$ de ancho y su profundidad es de 2,50 m (Podestá et al., 1997). Se destaca la utilización de pequeñas oquedades como soporte de las representaciones, las que por su diseño generalmente curvilíneo y redondeado, se adaptan a estas formaciones naturales, tiene un gran valor intrínseco por las pinturas rupestres que están sobre la roca. Desde el punto de vista geomorfológico, se observan gnammas o pilacones que son grietas sobre lanchares graníticos. Son poco profundas, de formas ovoides o esféricas y originadas por la meteorización alveolar, una forma de degradación físico-química en la roca. El lanchar es una superficie rocosa lisa, de cierta curvatura y de poca pendiente (Figura 7).

Entre los procesos propios de este tipo de relieve se reconocen planos de descamación, producidos por meteorización química y mecánica, ya sea por la incidencia del agua o de la diferencia térmica. El primero es producto de la meteorización química en la cual la roca se descama en forma de capas de cebolla y se denomina descamación esferoidal. En la Figura 8 se observan canales de drenaje en la roca de forma paralela que se encuentran controlados por la estructura y son recorridos por agua. 
Figura 6. Geoformas y procesos geomorfológicos en el valle de las Pinturas

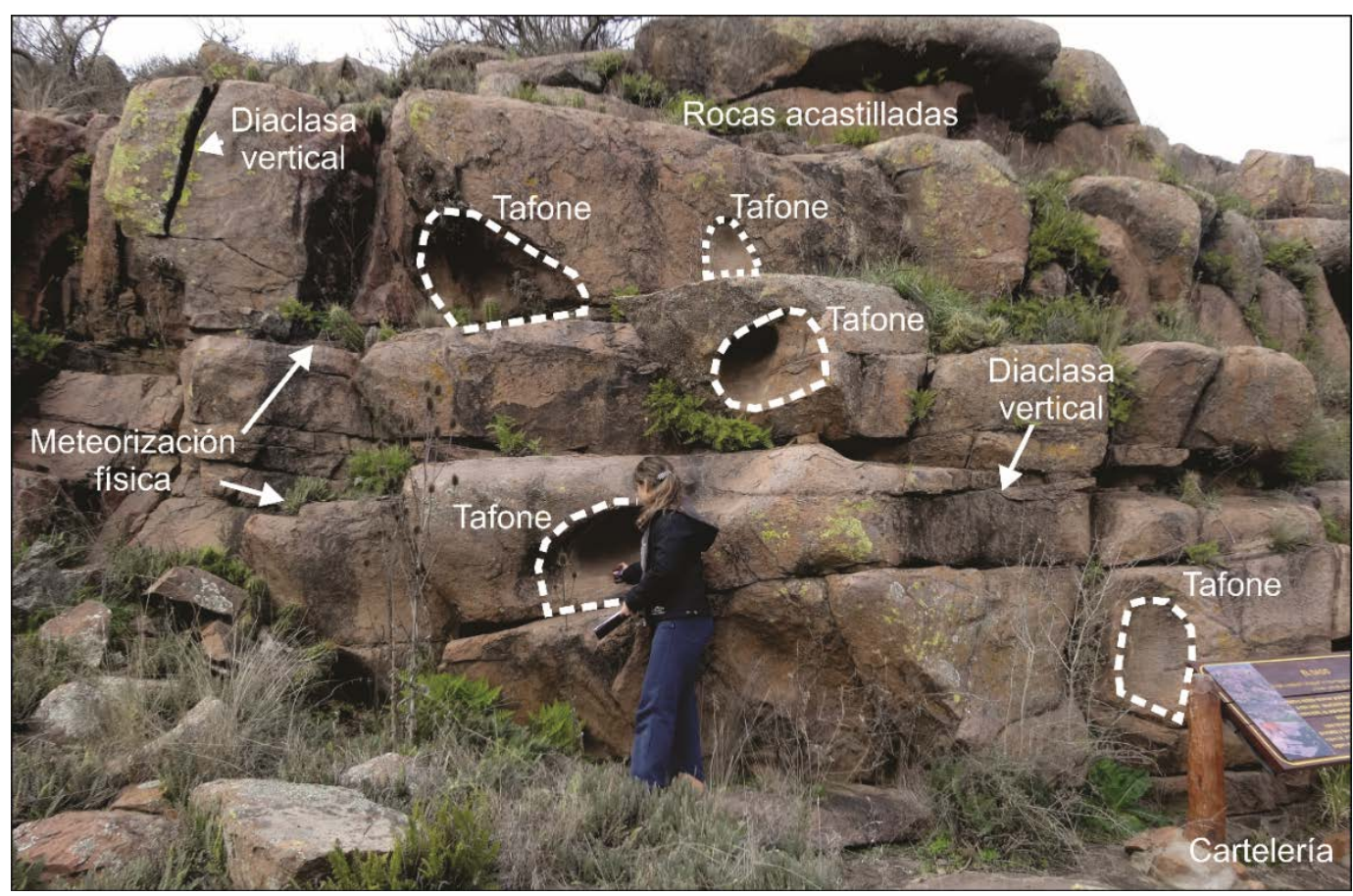

Fuente: elaboración propia

Figura 7. Geoformas en el alero de valle de las Pinturas

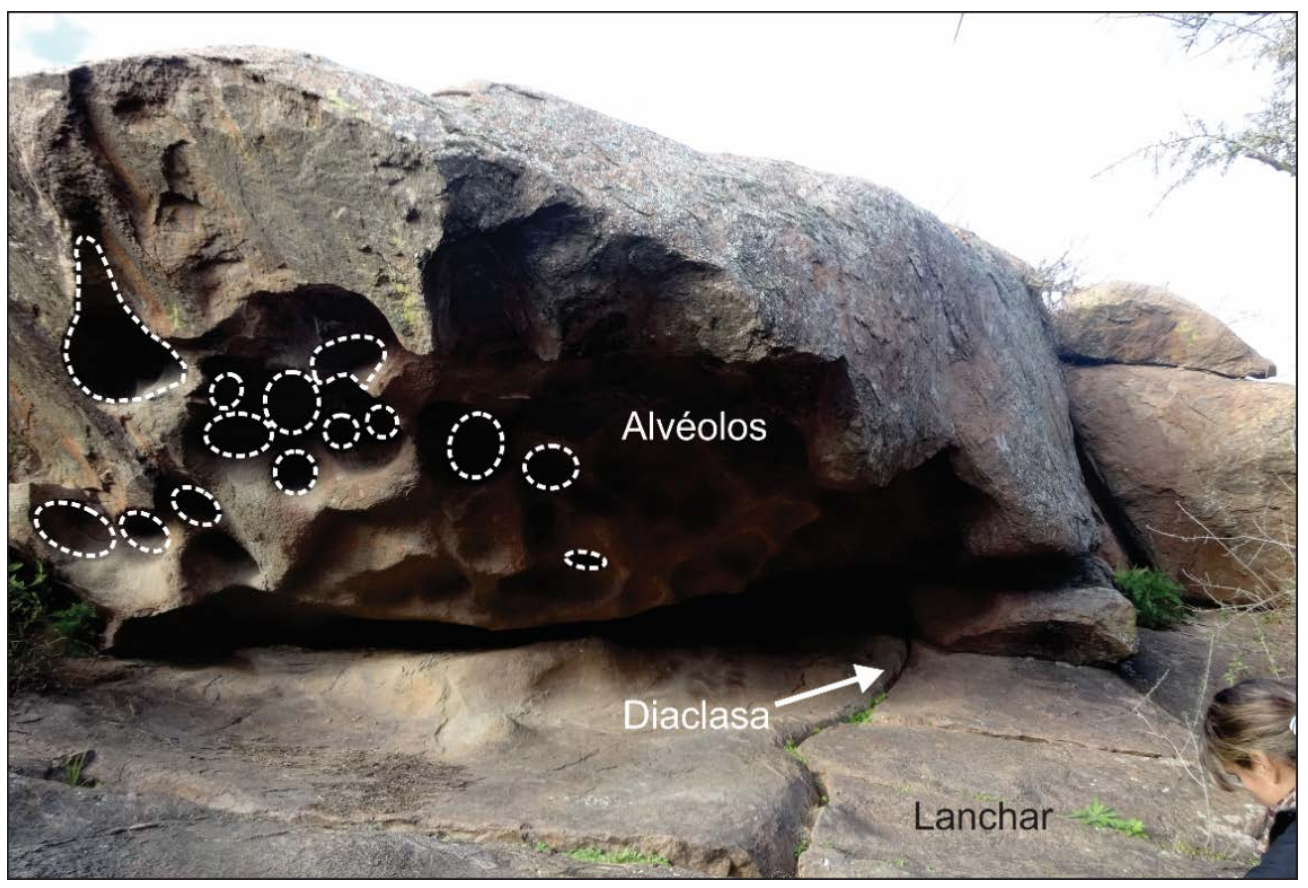

Fuente: elaboración propia 
Figura 8. Descamación esferoidal y canales de drenaje por diaclasas

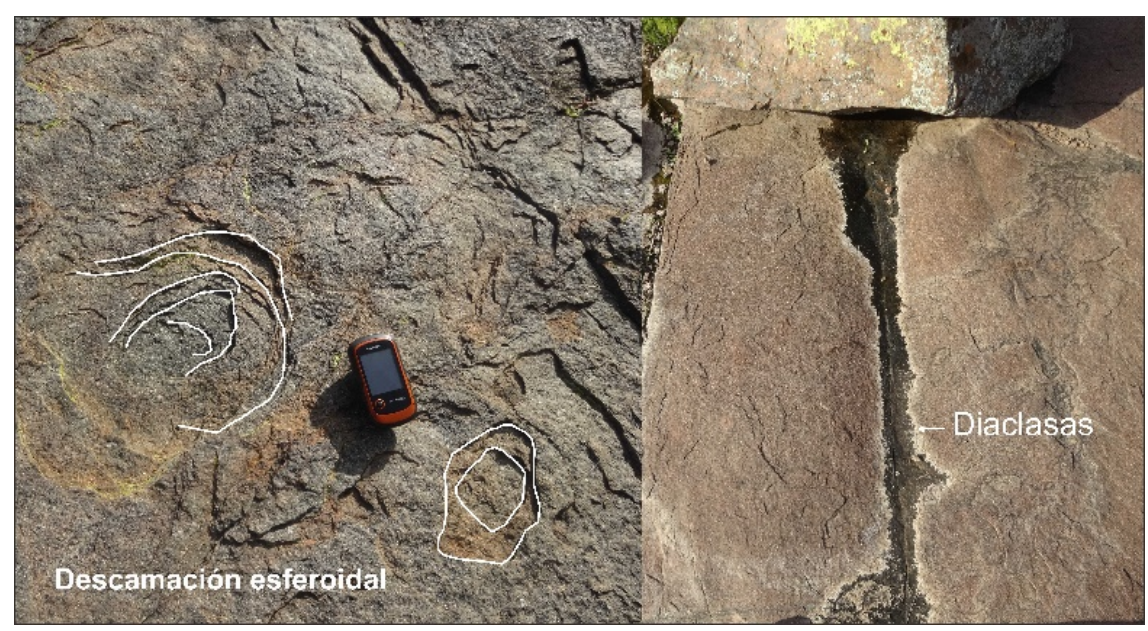

Fuente: elaboración propia

Otro geomorfositio es el cerro Alto o cerro de la Sociedad Científica. A diferencia del cerro de La Virgen, en este las geoformas primarias dentro del paisaje granítico presentan un grado de degradación menor con respecto a otros sitios antes mencionados en los cuales se observan geoformas como berrocales (Figura 9). En general los domos que se visualizan son los cupuliformes. Se observan también los bornhardts que son domos desnudos situados en laderas de gran pendiente y que pueden ser de tipo baleine o de dorsos de ballena. En el cerro Alto predominan los bornhardts de este segundo tipo que están biselados. Estos se encuentran unidos en pequeños grupos asociados a diaclasas verticales de exfoliación (Vidal Romaní \& Twidale, 1998), como también se registran formas graníticas menores como las gnammas, antes mencionadas. Las fracturas que se observan en la roca de las sierras de Lihué Calel son fracturas ortogonales. El patrón de drenaje se encuentra condicionado por el sustrato rocoso y por la pendiente. La roca posee porosidad y permeabilidad baja por lo que el agua penetra a través de las fracturas.

Este sitio posee un gran valor turístico dentro del parque nacional ya que es uno de los principales atractivos en el parque junto con el valle de las Pinturas. Hay un sendero denominado valle de Namuncurá a través del cual se asciende a la cima donde se encuentra el mirador. La duración estimada para el ascenso es de 2 horas y el trayecto recorrido es de 3000 m idea y vuelta. Este se encuentra señalizado con estacas que indican el camino más óptimo de ascenso. En cuanto al grado de dificultad si bien la cartelería lo categoriza como medio, el tipo de roca, la pendiente y la altura hace que la subida sea de grado elevado. El cerro posee, además, un alto valor científico y didáctico debido a que es un elemento de análisis geológico principalmente a nivel regional por su rareza y singularidad. Desde el punto de vista cultural, estas sierras ya fueron consideradas por los ranqueles como "sierras de la vida" ya que dentro de la pampa semiárida era el único lugar de refugio y aprovisionamiento de agua. 


\section{Figura 9. Geoformas identificadas en el Cerro Alto}

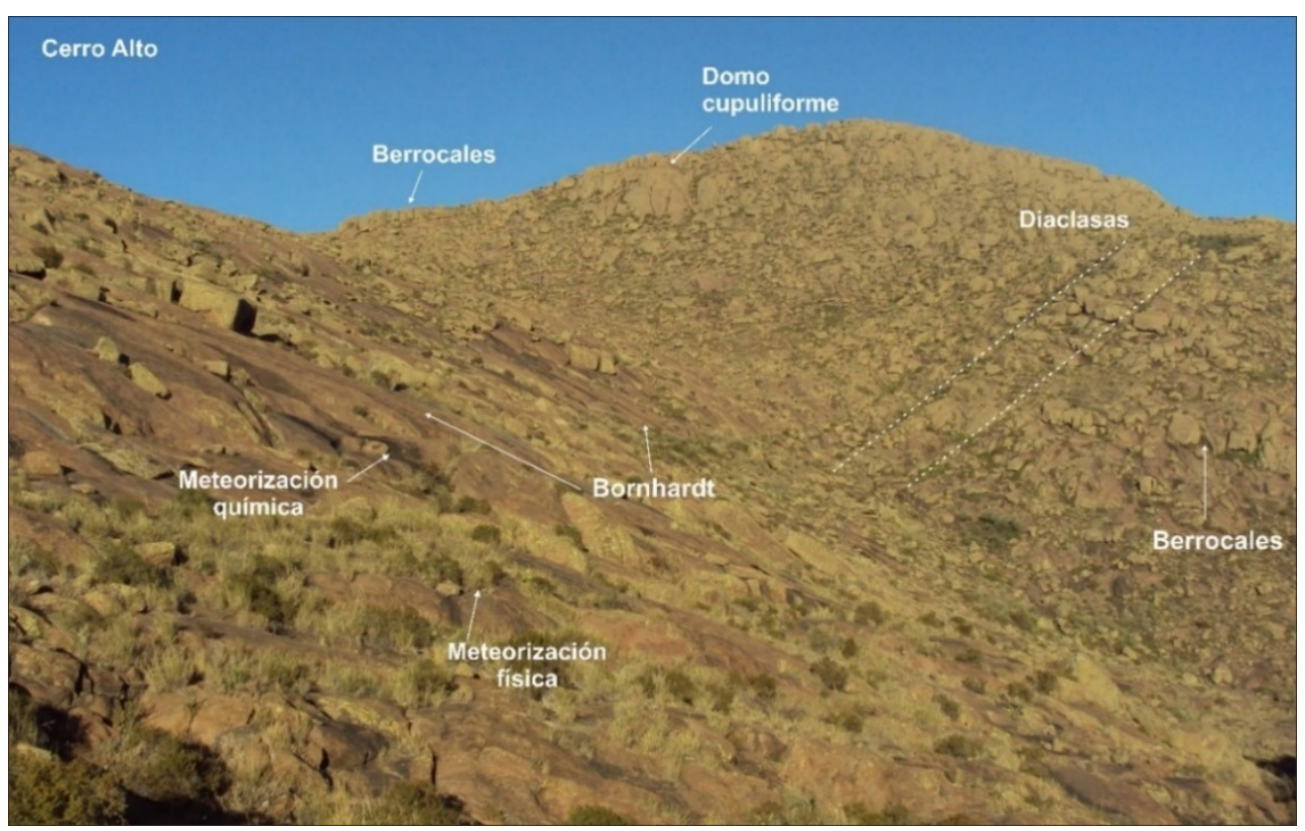

Fuente: elaboración propia

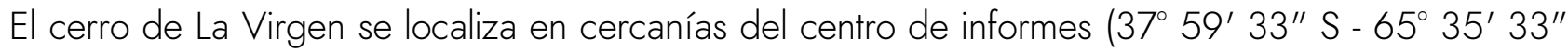
○). Se puede acceder a través de un circuito vehicular; no existen caminos para poder ascender o visualizar este paisaje de forma más cercana. No presenta dentro del parque un valor turístico y/o cultural en sí mismo aunque tiene gran valor científico y didáctico desde el punto de vista geológico y geomorfológico. Al ser un sitio sin acceso directo y ser nula la intensidad de uso, no presenta severos riesgos de degradación por acción humana. Por su litología es una roca susceptible a la fragmentación y a la alteración química. No obstante, su valor de conservación es muy alto. En cuanto a su valor intrínseco se pueden mencionar sus geoformas: se identifican los berrocales, las pedrizas y el pedimento. Los berrocales y las pedrizas constituyen la evolución de los domos graníticos. Son formas de evolución del paisaje granítico en la cual el diaclasado dominante es ortogonal casi cerrado en el primer caso y de mayor apertura en el segundo. La fracturación es discontinua en las pedrizas mientras que en los berrocales se observa solo en los bordes. Por su condición, las pedrizas están más meteorizadas en relación con los berrocales (Pedraza Gilsanz, 1996). El pedimento es una suave pendiente localizada sobre la base del escarpe compuesto, en este caso, por material granítico disgregado erosionado, característico de los climas semiáridos. Este pedimento se encuentra actualmente vegetado con herbáceas y, en menor medida, arbustivas (Vidal Romaní \& Twidale, 1998). Por último se menciona el proceso de disyunción columnar que es una forma de diaclasado vertical que se origina por contracción del material ignimbrítico. En la Figura 10 se muestran las geoformas y procesos antes mencionados, así como un cauce que se activa con las precipitaciones estivales. 


\section{Figura 10. Geoformas y procesos geomorfológicos en el cerro de la Virgen}

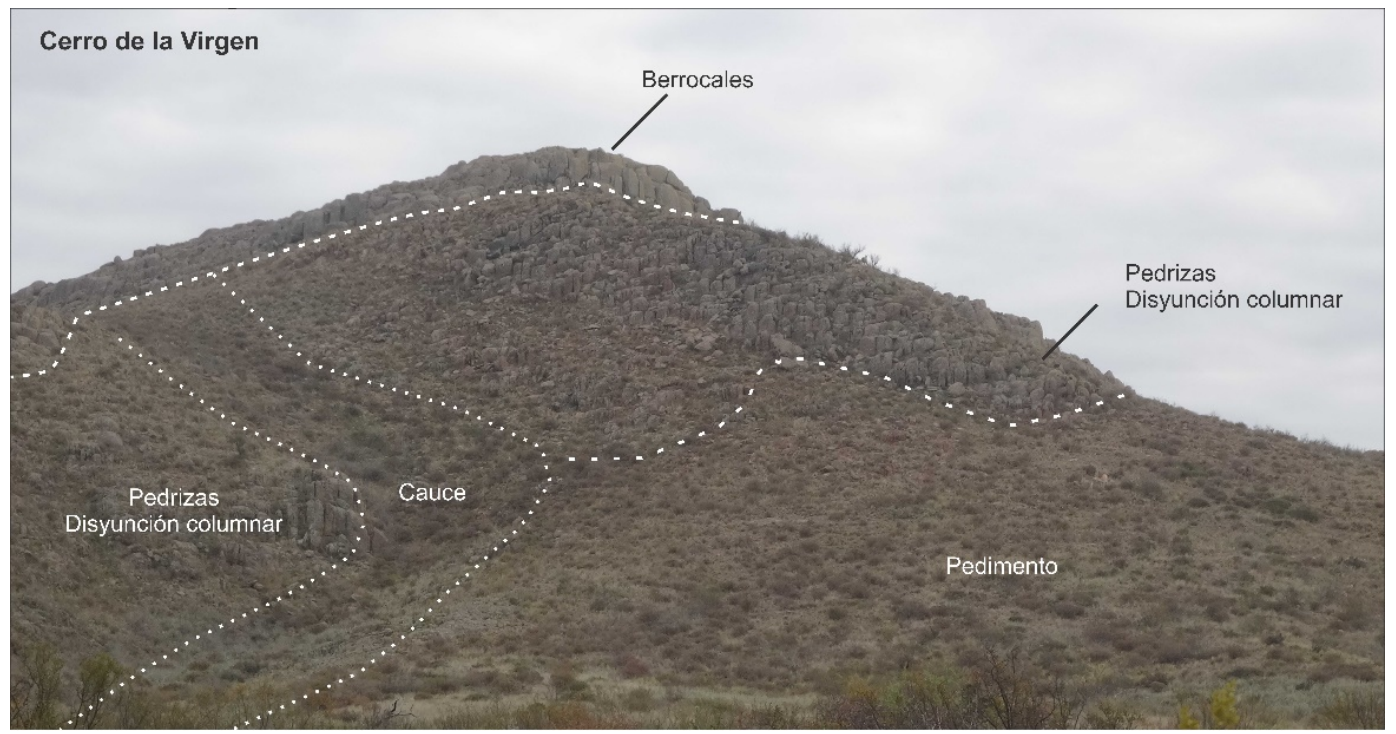

Fuente: elaboración propia

El cerro La Gloria (Figura 11) es otro geomorfositio de gran riqueza para visualizar. Se encuentra al sur del parque nacional y posee una altura aproximada de 496 m s.n.m. Su paisaje muestra rocas acastilladas o castle koppies que se encuentran atravesadas por diaclasas ortogonales. Sobre la base del cerro se observan residuales de berrocales cubiertos por la vegetación. Este sitio no posee actualmente valor turístico dentro del parque nacional. Si bien hay un camino vehicular que permite su acceso, este está cerrado al público; por lo tanto, tampoco hay señalización. El cerro La Gloria, al igual que el cerro Alto y el cerro de La Virgen, posee un alto valor científico y didáctico debido a que es un elemento de análisis geológico a nivel regional. En sí mismo no es un recurso principal, por lo que se debe ver como un elemento distintivo dentro del sistema de las sierras de Lihué Calel.

Las sierras Malas o Feas (Figura 12) se encuentran al suroeste del cerro Alto y poseen una altura aproximada de 451 m s.n.m., estas presentan diaclasas columnares y acanaladuras en el berrocal. En la parte baja, el berrocal se encuentra en un proceso de meteorización más avanzado y, por ende, aparecen las pedrizas. Actualmente este sitio no posee valor turístico dentro del parque nacional aunque hay un camino vehicular que permite su acceso. Este cerro, posee un alto valor científico y didáctico debido a que es un elemento de análisis geológico a nivel regional. No es un recurso principal, tan sólo es un elemento distintivo dentro del sistema de las sierras de Lihué Calel. Su vista es similar al cerro de La Virgen.

El sector del salitral es otro geomorfositio a conservar. Si bien no forma parte del paisaje granítico ni tampoco posee un elevado valor turístico o cultural, puede convertirse en un potencial atractivo del parque nacional. No hay ningún sendero o cartelería que indique que se pueda visitar el sitio. Es por lo tanto un atractivo turístico potencial que no presenta dificultad en sí mismo aunque su acceso 
desde el centro de información del parque es lejano. Sería recomendable realizar una nueva entrada al área protegida desde otro sector situado al noreste para facilitar su llegada. En período de precipitaciones, los caminos se anegan y por lo tanto se obstaculizan las únicas vías de comunicación. El área de salitral posee una valorización medio a bajo desde el punto de vista científico y didáctico. Posee un bajo valor cultural y el impacto sobre el área es también bajo.

Figura 11. Rocas acastilladas con diaclasas ortogonales en el cerro la Gloria

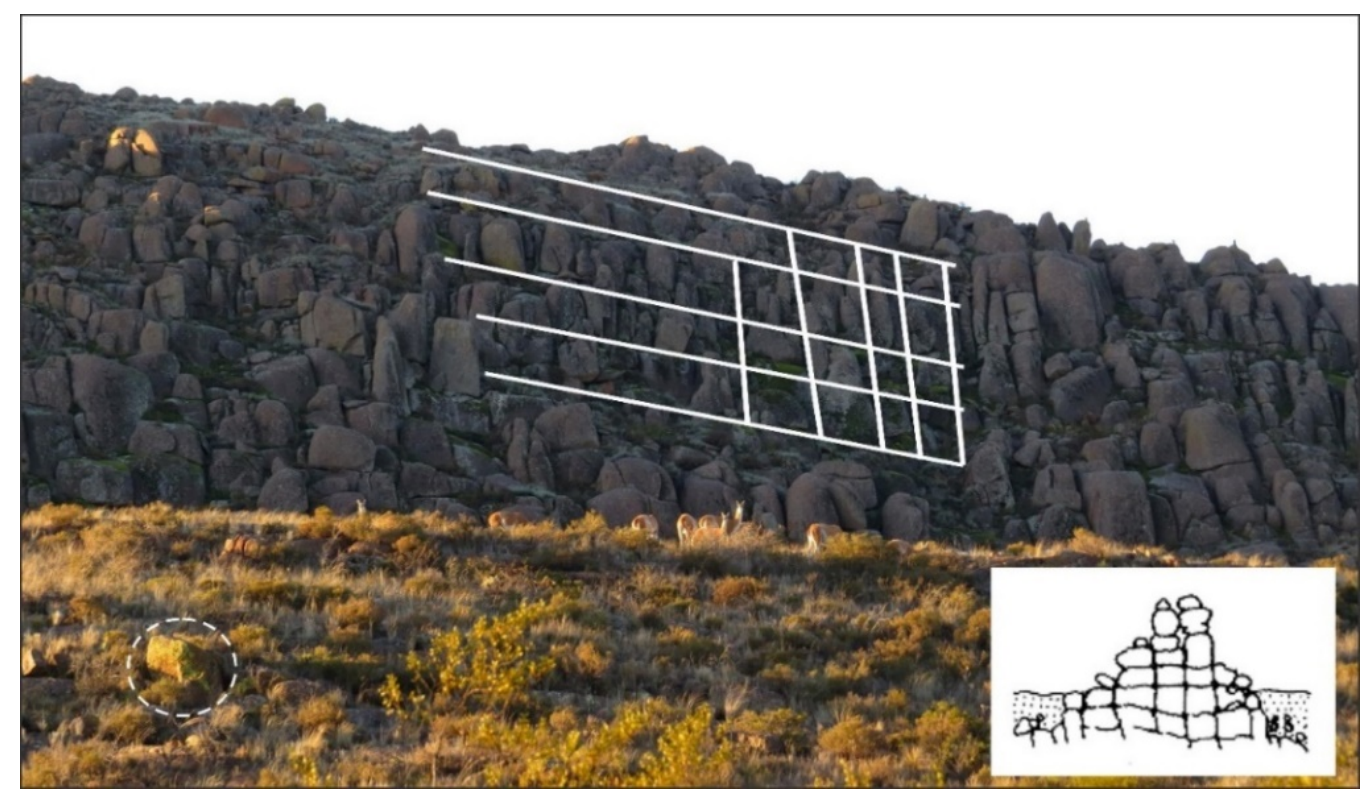

Fuente: elaboración propia sobre la fotografía de Miguel Ángel Romero (2016)

Figura 12. Berrocales y pedrizas en las sierras feas o malas

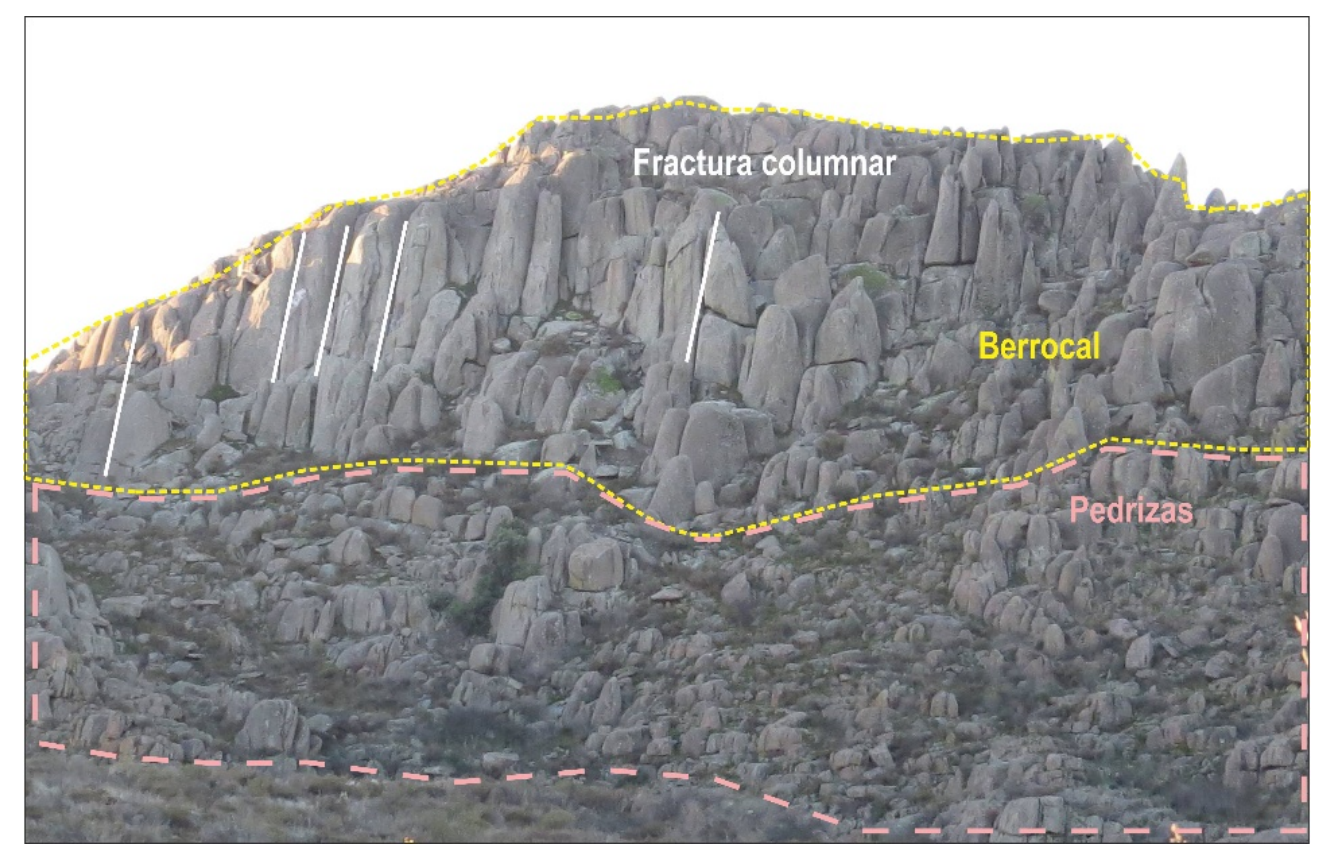

Fuente: elaboración propia sobre la fotografía de Miguel Ángel Romero (2016) 
El área de llanura es el de mayor superficie en el parque nacional y se caracteriza por ser una zona de acumulación aluvial y eólica que recubre el relieve de modelado granítico. Desde el punto de vista geomorfológico, no es un sector significativo. No hay ningún sendero y la cartelería que se observa es insuficiente. Es por lo tanto un atractivo turístico potencial que posee un acceso fácil y del cual se podría generar un mayor aprovechamiento. El área de llanura posee una valorización medio desde el punto de vista científico y didáctico aunque en este sector se puede estudiar la comunidad climácica de vegetación (el jarillal). Posee un bajo valor cultural y el impacto sobre el área es también bajo.

La valoración de estos geomorfositios se realizó considerando los valores intrínsecos, valores de uso y de gestión antes mencionados. El valor final del geomorfositio es una herramienta que se utilizó para realizar el mapa de geodiversidad del Parque. Los resultados de la valorización se muestran en la tabla 3. Se observa que el cerro Alto y el valle de las Pinturas poseen los valores más elevados en relación con los demás geomorfositios. El cerro La Virgen, cerro de La Gloria y Sierras Malas poseen un valor medio, son áreas con gran potencial para la visita y el área de salitral y llanura son los espacios con menor valoración.

Tabla 3. Valoración de los geomorfositios en Parque Nacional Lihué Calel

\begin{tabular}{|c|c|c|c|c|}
\hline $\begin{array}{c}\text { Sitios de interés } \\
\text { geomorfológico }\end{array}$ & $\begin{array}{c}\text { Valor } \\
\text { intrínseco }\end{array}$ & Valor añadido & $\begin{array}{c}\text { Valor de uso } \\
\text { y gestión }\end{array}$ & $\begin{array}{c}\text { Valor total del } \\
\text { geomorfositio }\end{array}$ \\
\hline Valle de las Pinturas & 5,2 & 6,7 & 7,2 & 6,4 \\
\hline Cerro Alto & 6,2 & 6,4 & 7,7 & 6,8 \\
\hline Cerro de La Virgen & 5,8 & 3,6 & 6,1 & 5,2 \\
\hline Cerro de La Gloria & 4 & 3,1 & 5 & 4 \\
\hline Sierras Malas & 4 & 2,7 & 5,5 & 4 \\
\hline Area del salitral & 3,2 & 2,6 & 6,1 & 3,9 \\
\hline Área de llanura & 2,6 & 2,3 & 5 & 3,3 \\
\hline
\end{tabular}

Fuente: elaboración propia

\subsection{Mapa de geodiversidad}

Como resultado de la valoración de los geomorfositios se realizó un mapa de geodiversidad (Figura 13) en el cual se evidencia que las zonas de nivel más alto de geodiversidad se localizan al sur del área protegida. Las mismas están asociadas con las áreas de recreación, donde están los senderos y que poseen un valor cultural y paisajístico mayor. Tal es el ejemplo del valle de las Pinturas que, como se destacó previamente, es un sitio que cuenta con los vestigios de los pueblos originarios así como la historia de ocupación del parque en ese período y se encuentra rodeado por un paisaje granítico excepcional. El cerro Alto es otro geomorfositio de alto valor de geodiversidad. En él se encuentran distintas geoformas de relieve granítico, su escalada es a su vez uno de los atractivos más importante y es un recurso didáctico por excelencia. Los valores medios corresponden al resto de los cerros que conforman el sistema de las sierras de Lihué Calel que, si bien tienen numerosas 
geoformas interesantes, no cuentan con ninguna accesibilidad por parte de los visitantes, ni promoción por parte del parque nacional. Poseen valor didáctico perteneciente a un nivel educativo superior y son recursos de interés.

Figura 13. Mapa de geodiversidad del Parque Nacional Lihué Calel

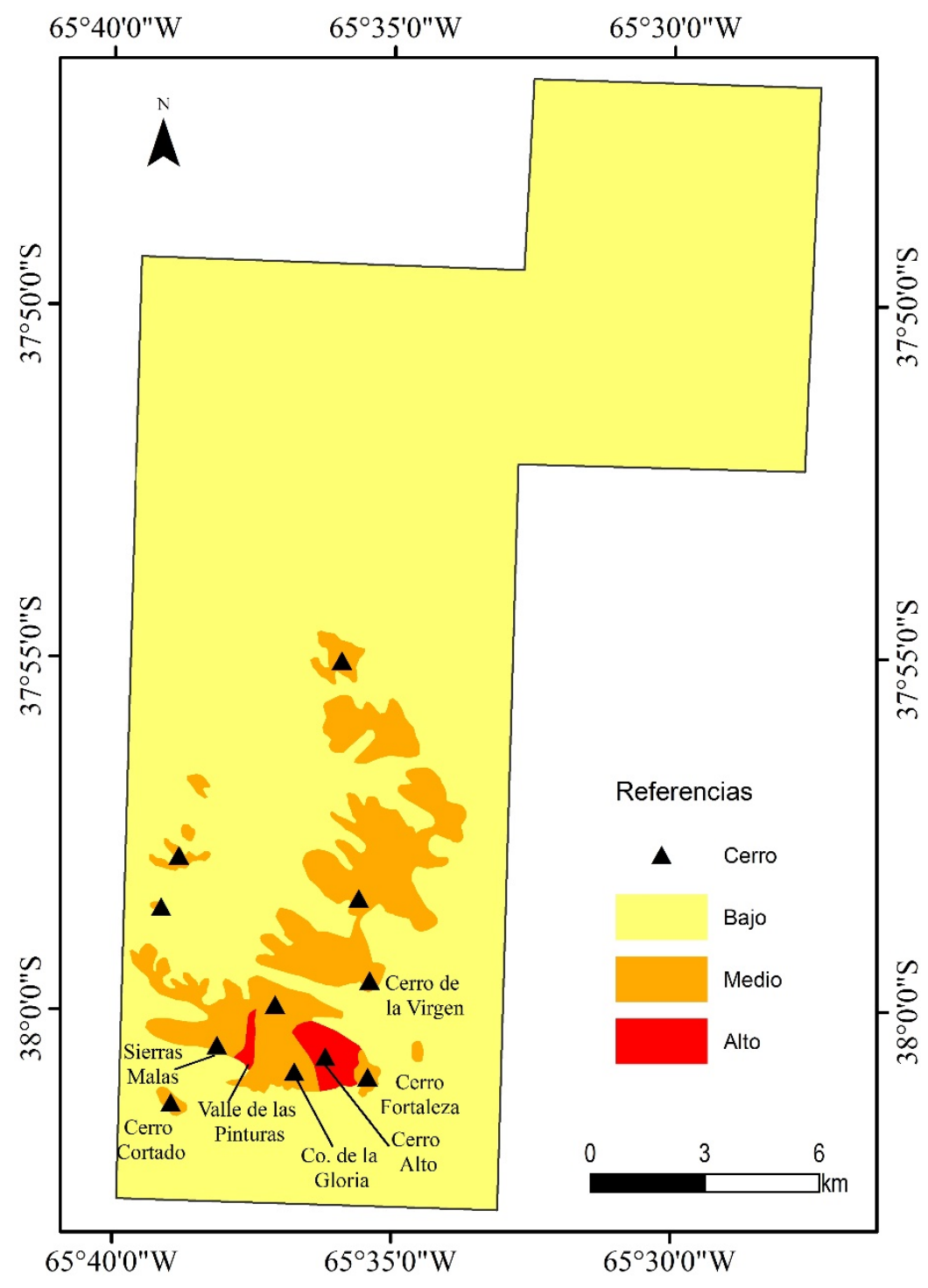

Fuente: elaboración propia

Los valores más bajos de geodiversidad están representados por el salitral y por la llanura del parque nacional. En cuanto al salitral Levalle, su ambiente reviste una gran importancia principalmente por su biodiversidad ya que se encuentran plantas halófilas por ser un ambiente salino. No se destacan importantes geoformas desde el aspecto geomorfológico. La accesibilidad a esta área resulta compleja ya que se halla a una distancia de $15 \mathrm{~km}$, en línea recta, de la entrada del parque por el sur y solo se puede acceder a este sector por medio de un vehículo. No existe ningún sendero que permita revalorizar su paisaje. Por otra parte, el área de llanura presenta el valor más bajo debido a que no cuenta con importante riqueza intrínseca. 


\subsection{Propuesta para la valorización de los geomorfositios}

Las geoformas graníticas representan un componente esencial de la identidad de La Pampa. Asociados a estas formas se encuentra el valor cultural y científico, antes mencionado, que debe ser reconocido y mostrado al público para que se comience a valorarlo como tal. El Parque Nacional Lihué Calel ofrece un sendero de ascenso al cerro Alto en el cual se puede observar el inselberg en el medio de la llanura pampeana. Existe poca información sobre el aspecto paisajístico del relieve granítico, encontrándose en el centro de interpretación solo el origen de las sierras. Es por eso, que como resultado del análisis de los geomorfositios se busca priorizar el objetivo de creación de esta área protegida y crear propuestas para la valorización de la geomorfología.

Los senderos en un área protegida son importantes ya que cumplen una doble función: es una actividad de recreación al visitante y, a la vez, un espacio de educación ambiental y valorización del patrimonio natural y cultural. En el parque nacional hay senderos que resaltan la biodiversidad y paisaje del área, aunque en relación con la geodiversidad, no hay un sendero específico que informe y muestre la relevancia de este relieve. El sendero Namuncurá permite el ascenso a la cima pero carece de paradas informativas con una explicación de las geoformas e importancia como parte de la geodiversidad. Se propone revalorizar las formas del relieve a través de la creación de senderos autoguiados que estén destinados a la valorización de las sierras de Lihué Calel. Se plantean dos opciones: (i) una peatonal en el cual las personas puedan apreciar las geoformas del paisaje granítico del cerro de La Virgen, cerro Alto y cerro de la Cruz. El camino es utilizado para el acceso a las pinturas rupestres; (ii) y otra un sendero vehicular en el cual se pueden realizar cinco paradas: el cerro Fortaleza, cerro Alto, cerro de la Gloria, sierras Malas y cerro Cortado (Figura 14). Cada uno de estos puntos panorámicos debe contar con un cartel en el cual se expliquen las geoformas y su origen. También se pueden agregar imágenes en las cuales se muestre este relieve en otras partes del mundo. Este sendero debe ser reacondicionado debido a que no es de acceso público. Es necesario realizar un estudio de su capacidad de carga para verificar si es factible su creación. Cada uno debe contar con sillas y miradores además de la cartelería para que los visitantes puedan descansar y disfrutar del patrimonio geomorfológico.

Por otra parte, en el contexto del turismo aventura se busca fomentar actividades de escalada y tirolesa en algunos cerros. Dentro del Parque Nacional Lihué Calel sería una buena alternativa como parte del turismo aventura. Se propone que desde la administración y gestión del área protegida se defina un sitio en el cual se puedan realizar la escalada con el material necesario para la misma. Esta práctica debe ser regulada para que no genere impactos negativos sobre el medio-ambiente, se debe identificar un cerro en el cual se pueda realizar la actividad y, de implementarse, debe ser controlada por al menos un guardaparque. En el año 2012, los guardaparques de esta área protegida recibieron una capacitación sobre cómo realizar la escalada y las recomendaciones que se deben considerar (Figura 15). 
Figura 14. Senderos propuestos en el Parque Nacional Lihué Calel

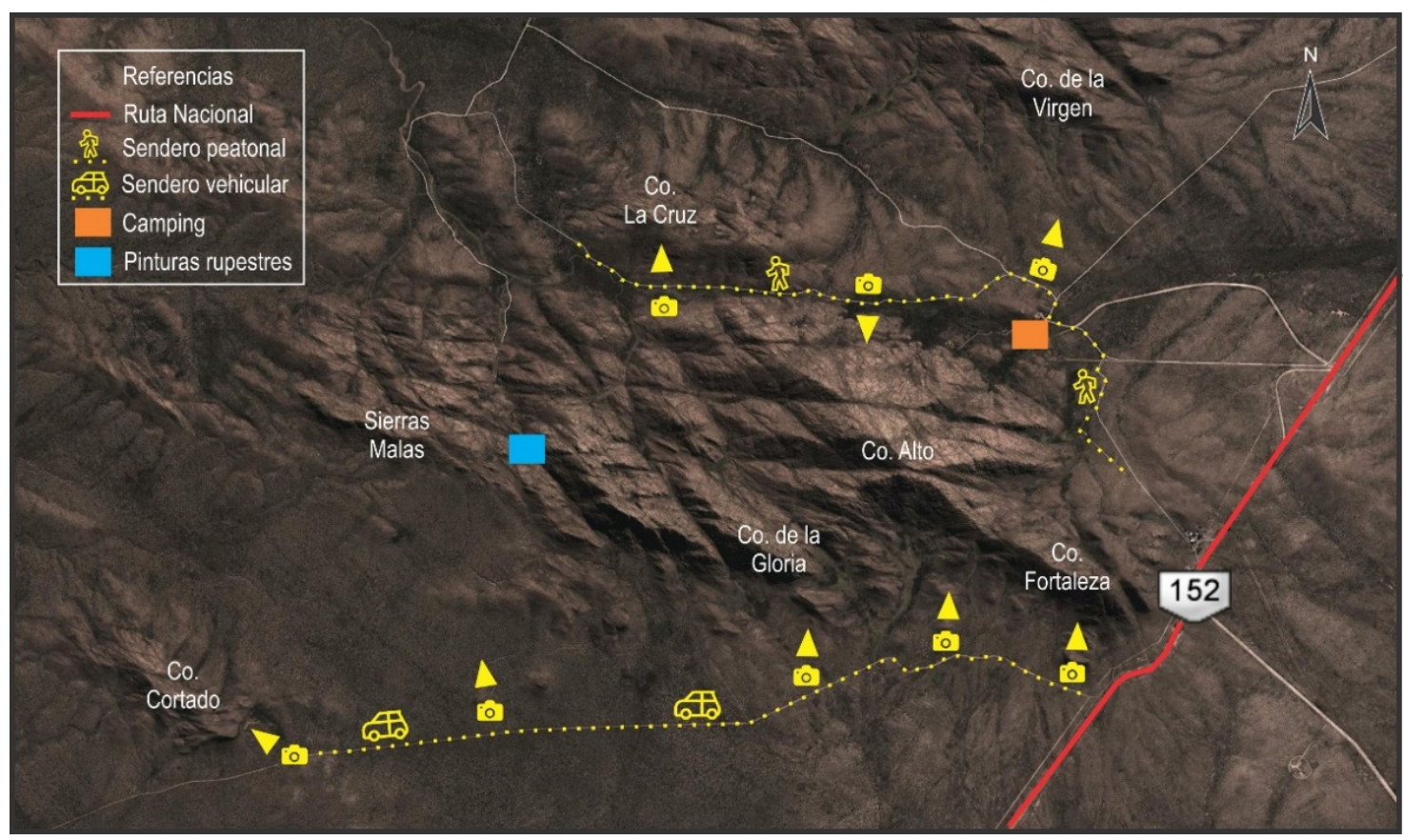

Fuente: elaboración propia

Figura 15. Escalada en el Parque Nacional Lihué Calel

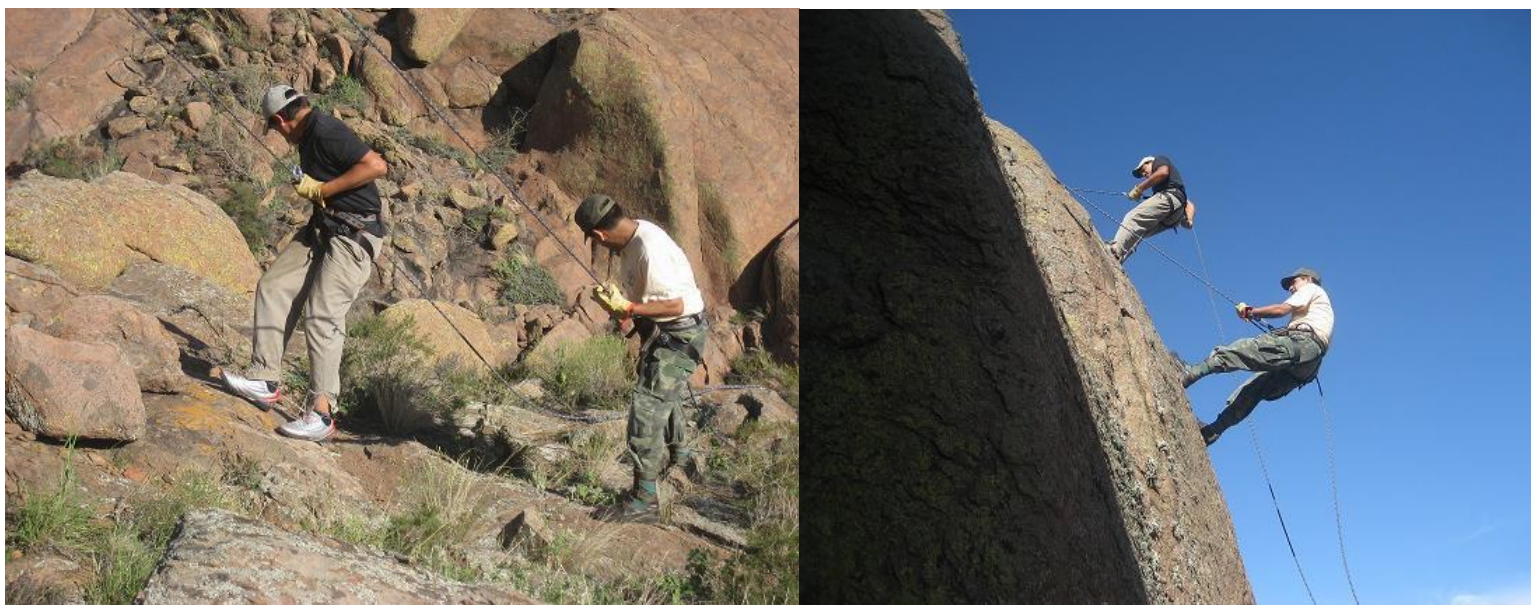

Fuente: Miguel Ángel Romero (2012)

\section{Conclusión}

Los geomorfositios son lugares de gran valor geomorfológico y geológico y se constituyen en instrumentos de gestión territorial en las áreas protegidas. En Argentina, estos sitios comenzaron a ser relevantes en las últimas décadas ante la posibilidad de su pérdida irreversible y frente a la necesidad de reflexionar sobre la falta de conocimiento y carencia de su valorización como parte del patrimonio natural inerte.

El Parque Nacional Lihué Calel se creó para conservar las sierras homónimas. En este relieve granítico de aproximadamente 240 millones de años, se pudieron identificar geoformas mayores y 
menores como por ejemplo domos y berrocales en el primer grupo y tafonis y alvéolos en el segundo grupo. La valorización de las sierras desde el punto de vista de la geodiversidad tiene actualmente poco desarrollo. Es por ello que se reconocieron los principales sitios de valor geomorfológico y se detectaron siete áreas: el cerro Alto, el valle de las Pinturas, el cerro La Gloria, el cerro de La Virgen, las Sierras Malas, el área de llanura y el área del salitral. De cada una de ellas se valorizó sus características intrínsecas, los añadidos, de uso y gestión para cuantificar su valor de geodiversidad. Como resultado, se observó que el cerro Alto y el valle de las Pinturas tienen los valores más elevados en relación con los demás geomorfositios. El cerro La Virgen, cerro de La Gloria y Sierras Malas poseen un valor medio con un gran potencial para la visita y el área de salitral y llanura son los espacios con menor valoración.

A partir del mapa de geodiversidad y de la valoración de los geomorfositios se realizaron distintas propuestas para la gestión de los recursos del parque nacional en el espacio de uso público. Entre ellas se definieron dos senderos, uno peatonal y otro de acceso vehicular, que permiten a través de paradas con cartelería sobre las geoformas y paisaje, comprender la importancia de este relieve en la provincia. Por otra parte, se propone la realización vigilada de actividades de turismo aventura como por ejemplo la escalada y la tirolesa. Estas actividades permitirán generar otro ingreso para el parque nacional y posibilitará un acercamiento de los visitantes al paisaje pampeano, así como una sensibilización sobre el cuidado del medioambiente y la valoración de este patrimonio geomorfológico.

Agradecimientos: Las autoras agradecen al proyecto Geografía Física aplicada al estudio de la interacción sociedad-naturaleza. Problemáticas a diferentes escalas témporo-espaciales, en el cual se desarrolló este estudio. El proyecto es dirigido por la Dra. Alicia M. Campo y es financiado por la Secretaría de Ciencia y Tecnología de la Universidad Nacional del Sur. Al Consejo Nacional de Investigaciones Científicas y Técnicas (CONICET) por ser la institución en la cual se enmarca nuestro trabajo de investigación. Finalmente agradecer a las autoridades de la Administración de Parques Nacionales por permitirnos trabajar en el área y apoyar nuestras actividades de investigación.

Declaración responsable: Las/os autoras/es declaran que no existe ningún conflicto de interés en relación a la publicación de este artículo. Valeria Soledad Duval y Alicia María Campo realizaron la revisión bibliográfica e hicieron los trabajos de campo correspondientes en el Parque Nacional Lihué Calel. Ambas identificaron y valorizaron los geomorfositios y obtuvieron las fotografías de los sitios. Posteriormente procesaron la información y redactaron los resultados, describiendo con detalle cada sitio relevado. Valeria Soledad Duval elaboró la cartografía correspondiente al área de estudio, localización de los cerros y mapa de geodiversidad. 


\section{Bibliografía}

Aguilera, E., Sato, A. M., Llambías, E., \& Tickyj, H. (2014). Erosion Surface and Granitic Morphology in the Sierra de Lihuel Calel, Province of La Pampa, Argentina. In J. Rabassa \& C. Ollier (Eds.), Gondwana Landscapes in the southern South America. Argentina, Uruguay and southern of Brasil (pp. 393-422). Dordrecht: Springer Netherlands.

Artugyan, L. (2014). Geomorphosites as a valuable resource for tourism development in a deprived area. The case study of Anina Karstic Region (Banat Mountains, Romania). Analele Universităţiidin Oradea, Seria Geografie, 2, 89-100.

Bazán, H. (2016). Aprovechamiento didáctico y turístico del patrimonio geomorfológico a través de la interpretación del patrimonio. Presented at the XI Jornadas de Geografía Física (pp. 1-10).

Cabrera, A. (1976). Regiones fitogeográficas argentinas. In D. Parodi, Enciclopedia argentina de agricultura y jardinería (pp. XX-XX). Buenos Aires, Acme.

Ferraro, L. (2010). La práctica social actual: conservación y visitación del arte rupestre del Parque Nacional Lihué Calel. In M. Berón, L. Luna, M. Bonomo, C. Montalvo, C. Aranda, M. Carrera Aizpitarte, Mamül Mapu: pasado y presente desde la arqueología pampeana (pp. 215-226). Buenos Aires, Editorial Libros del Espinillo.

González Amuchastegui, M. J., Serrano Cañadas, E., \& González García, M. (2014). Lugares de interés geomorfológico, geopatrimonio y gestión de espacios naturales protegidos: el Parque Natural de Valderejo (Álava, España). Revista de Geografía Norte Grande, 59, 45-64. Retrieved from http://www.scielo.cl/pdf/rgeong/n59/art04.pdf

González Trueba, J., \& Serrano Cañadas, E. (2005). Glaciarismo histórico en los picos de Europa (NO España). Factores condicionantes y deglaciación. Boletín Glaciológico Aragonés, 6, 37-60.

González Trueba, J., \& Serrano Cañadas, E. (2008). La valoración del patrimonio geomorfológico en espacios naturales protegidos. Su aplicación al parque nacional de los picos de Europa. Boletín de la Asociación de Geógrafos Españoles, 47, 175-194. Retrieved from http://age.ieg.csic.es/boletin/47/09-GONZALEZ.pdf

Leynaud, G. (2002). Inventario y caracterización de los puntos de interés geológico (PIG) de la provincia de Córdoba. Presented at the XV Congreso Geológico Argentino.

Linares, E., Llambías, E., \& Latorre, C. (1980). Geología de la provincia de La Pampa, República Argentina y geocronología de sus rocas metamórficas y eruptivas. Revista de la Asociación Geológica Argentina, XXXV(1), 87-146.

Llambías E. J, \& Leveratto, M. A. (1975). El plateau riolítico de la provincia de La Pampa, República Argentina. In Actas /l Congreso Iberoamericano de Geología Económica, n 1, 99-114. 
Llambías, E. J. (2008). La sierra de Lihuel Calel. Volcanismo explosivo acontecido hace 240 millones de años. In Sitios de Interés Geológico de la República Argentina (pp. 537-550). Buenos Aires: Servicio Geológico Minero Argentino.

Martín Sánchez, S. J., \& Rebollada Casado, E. (2010). Génesis y evolución de las geoformas en el monumento natural Los Barruecos, Malpartida de Cáceres (Cáceres, España). In E. Romero Macías (Coord.), Una apuesta por el desarrollo local sostenible (pp. 121-130). Huelva: Universidad de Huelva. Retrieved from

https://www.academia.edu/3477623/G\%C3\%A9nesis_y_Evoluci\%C3\%B3n_de_las_Geoformas_ en_el_Monumento_Natural_de_Los_Barruecos

Martínez, O. (2008). Patrimonio geológico. Identificación, valoración y gestión de sitios de interés geológico. Geograficando, $\quad$ M(4), 233-250. Retrieved from http://www.memoria.fahce.unlp.edu.ar/art_revistas/pr.3748/pr.3748.pdf

Medina, W. M. (2014). Propuesta Metodológica para el inventario del patrimonio geológico de Argentina. Braga: Universidade do Minho, Escola de Ciências.

Mendoza Ontiveros, M., Umbral Martinez, M. E., \& Arévalo Moreno, M. N. (2011). La interpretación del patrimonio, una herramienta para el profesional de turismo. El Periplo Sustentable, 20, 9-30. Retrieved from http://www.redalyc.org/articulo.oa?id=193417856002

Mikkan, R. (2016). Patrimonio geomorfológico, identificación y valoración de sitios de importancia geomorfológica. Presented at the XI Jornadas de Geografía Física (pp. 1-11).

Palacio Prieto, J. L. (2013). Geositios, geomorfositios y geoparques: importancia, situación actual y perspectivas en México. Investigaciones Geográficas, 82, 24-37. Retrieved from http://www.investigacionesgeograficas.unam.mx/index.php/rig/article/view/32817/33715

Palacio Prieto, J. L. (Coord.) (2016). Patrimonio geológico y su conservación en América Latina: Situación y perspectivas nacionales. México: Universidad Nacional Autónoma de México, Instituto de Geografía. Retrieved from http://www.publicaciones.igg.unam.mx/index.php/ig/catalog/view/77/77/236-1

Pedraza Gilsanz, J. (1996). Geomorfología. Principios, métodos y aplicaciones. Madrid: Editorial Rueda.

Peña Monné, J. (Ed.). (1997). Cartografía, geomorfología básica y aplicada. Zaragoza: Geoforma Ediciones.

Podestá, N. M., Rolandi de Perrot, D., \& Onetto, M. (1997). Un plan para la preservación y administración de los sitios con arte rupestre en la Provincia de La Pampa, República Argentina. In Ciudad Arqueología. Retrieved from http://rupestre.equiponaya.com.ar/articulos/rup13.htm 
Pol, L., Camín, S. R., \& Astié, A. (2006). Situación ambiental en la ecorregión del Monte. In R. Burkart, N. O. Bárbaro, R. O. Sánchez \& D. Gómez, Ecorregiones de la Argentina. (pp. 227233). Buenos Aires: Orientación gráfica editora.

Reynard, E., \& Panizza, M. (2007). Geomorphosites: definition, assessment and mapping. Géomorphologie: relief, processus, environnement, 3, 177-180.

Vidal Romaní, J. R., \& Twidale, C. R. (1998). Formas y paisajes graníficos. Coruña: Universidad de Coruña. 